\title{
A Multicriteria Model to Evaluate Strategic Plans for the Nautical and Naval Industry in Cartagena de Indias, Colombia
}

\author{
Hannia Gonzalez-Urango * and Mónica García-Melón \\ Ingenio (CSIC-UPV), Universitat Politècnica de València, 46022 Valencia, Spain; mgarciam@dpi.upv.es \\ * Correspondence: hangonur@doctor.upv.es; Tel.: +34-627-117-114 \\ Academic Editor: Tan Yigitcanlar \\ Received: 22 March 2017; Accepted: 14 April 2017; Published: 20 April 2017
}

\begin{abstract}
The evaluation of urban development plans is a key concern of the strategic planning of the city of Cartagena de Indias (Colombia) due to the pressure exerted by both public and private sectors. Any strategic planning requirement deserves the inclusion of clear terms of coordination and cooperation among sectors, including local communities and the scientific sector. In this paper, we present a methodology for the sustainable evaluation of strategic nautical and naval projects for the development of the city of Cartagena de Indias. The methodology is based on the multicriteria technique Analytic Network Process, which allows considering political, socio-cultural and environmental aspects. The aim is to provide answers and guide the decision makers towards the optimal selection of strategies. Results provide some important insights into the overall conception of what sustainable evaluation means for the experts consulted. The procedure enhances participation and transparency and becomes a support for their decisions.
\end{abstract}

Keywords: analytic network process (ANP); Cartagena de Indias; nautical industry; naval industry; sustainable evaluation

\section{Introduction}

Coastal and marine ecosystems are among the most productive, yet highly threatened, systems in the world [1]. They are being altered continuously by the pressure generated as a result of the infrastructure increase needed to sustain residential, commercial and touristic operations related to human activity development [2-7].

Of all marine activities, the nautical and naval industries are among the most significant and fastest growing industries. Their importance lies in their high added value and their impact in job generation [8,9]. Specifically, in the recreational nautical sector, according to the International Council of Marine Industry Associations ICOMIA [10], there are more than 100000 companies throughout the world, generating more than one million jobs and more than $€ 40$ million in annual revenues. Although the amounts of recreational vessels throughout the world is only an estimate, sector statistics indicate that there are nearly 25 million of them, close to 25000 marinas and more than 700 new mega yachts under construction [10]. Good predictions for this sector are maintained, and, for 2030, the marine industry is expected to duplicate its actual power. In particular, the commercial maritime transport, the naval and offshore energy production sectors are expected to grow [11].

However, activities related to the nautical and naval sector are responsible for high water and air contamination levels. Consequently, recent literature has witnessed strong debates, controversy and contradictions among economic sectors and several groups over maritime use interaction $[2,8,12]$. Therefore, its expansion must be very carefully studied and considered. 
Colombia has a great development potential in its nautical recreational sector. First, thanks to its location outside the hurricane belt and on the main international navigation routes. It has extensive coastal lines over the Pacific and Atlantic oceans $(3800 \mathrm{~km})$, several water bodies across the length and breadth of the country (18000 km of navigable rivers, 1800 lagoons, and 1900 reservoirs), a wide and recognized touristic offer, a growing integration into international markets and a positive international perception after the peace agreement signing $[13,14]$. Additionally, the solid growth of the main world markets, such as the United States market, the increase of ship moorings' demand and the construction of several small sports marinas and touristic facilities all over the world, has to be considered [5,7].

Cartagena de Indias is one of Colombia's main cities located on the country's northern coast. It is favored by its good morphologic and location conditions, thanks to its proximity to the Panama Canal. The city is recognized by its natural attractions and its historical heritage, which has benefited the development of its nautical and naval industry. Thus, Cartagena de Indias represents the epicenter of the activity in the Colombian Caribbean with the highest offer of nautical facilities and related services [15-17].

Along the city's coastline, a variety of coastal structures can be found, over which an important proportion of their main economic activities take place [15]. Much like other coastal cities, several controversies have been generated in Cartagena over the expansion and placement of new nautical facilities, considering the high urban density in some areas, the involved areas protection, new activities development and the enhancement of the already existing activities. These actions sometimes contradict each other and compete for the same limited resources and/or spaces $[7,18,19]$. Thus, in terms of planning and management of local development, it is very important to identify places for the location and expansion of nautical and naval facilities in adequate areas in the coastal zone, so it is essential to adopt an integrated approach to address these multifaceted issues [2].

Any environmental planning requirement deserves the inclusion of clear terms of coordination and cooperation among sectors, including local communities and the scientific sector $[1,6]$. Many efforts have been made within the European Community (EC) to put environmental participative processes into practice since the EC signed the Aarhus Convention on access to information, public participation in decision-making and access to justice in environmental matters [20]. The first two have been transposed in Directives 2003/4/EC on "public access to environmental information" [21], and 2003/35/EC on "providing for public participation in respect of the drawing up of certain plans and programs relating to the environment" [22]. Some recent publications in the field of sustainable planning also stress the importance of these participatory processes [23]. The achievement of an optimal solution for all of the stakeholders becomes difficult when the intervention of different agents, objectives and factors is considered [24]. Although Colombia is not part of the EC, the authors have considered relevant to include these issues.

Recent conceptualizations of the coast as a "commons" facilitate the view of this area as a holistic, interconnected, complex social-ecological system [25] where different users have different and, sometimes, conflicting interests [3]. Therefore, coastal space planning and ordination must consider methodologies that take this complexity into account. Complex approaches on linear analysis are preferred, as well as multidisciplinary and multisectoral approaches [6].

Domínguez-Tejo et al. [26] in their work on social, economic and environmental values integration into the analysis of land-use planning and regulations, in the context of coastal and marine space planning, indicate the need to implement better methodological frameworks and clearer execution guidelines to be incorporated into spatial planning decisions. Moreover, they consider the existence of an important knowledge gap when trying to improve the integrated management approach in marine resources planning. Izadikhah and Saen [27] try to fill this gap in their study of a new method of preferential voting for sustainable location planning, a technique of multicriteria decision making based on Data Envelopment Analysis (DEA), criteria assessment and the use of Geographic Information System (GIS). However, they recognize, at the end of their work, that their proposal can be enhanced 
by a Multiple Criteria Decision Making (MCDM) technique such as the Analytical Hierarchy Process (AHP). Moreover, they do not consider interdependence between criteria.

In the specific case of Cartagena, planning processes are under the pressure of public and private sectors, but, mainly, of its citizens. They demand developments that not only generate income to certain private sectors of the city, but also these developments should recognize the value of the coastal and marine spaces in the wellbeing generation for its residents [7]. Therefore, the city needs to understand that a more explicit and integrated inclusion of trade-offs and synergies among ecosystem services will make coastal strategic planning more adaptive and sustainable, and that a structured method to assess this inclusion is needed [28].

The analysis of the environment by a multicriteria analysis will provide answers and orient the decision-maker towards the selection of the facilities of a nautical infrastructure [29]. Thus, the arguments expressed that lead to defining that strategic planning for the nautical and naval industry in Cartagena de Indias should be treated as a multicriteria decision problem. Therefore, this work's objective is to show how a multicriteria technique (MCDM) such as the Analytic Network Process (ANP) is useful for prioritizing local development strategies. It is the first time that this type of exercise is developed for the nautical and naval sector in Cartagena. The model is carried out with the participation of actors from different sectors, the alternatives were preconceived for different local and national plans and programs, and the criteria were selected to seek sustainability and expansion of this sector. With the aim of verifying in practice the relevance and usefulness of this methodology and to draw some conclusions on their potentialities and limitations, this work intends to prove that ANP is an appropriate tool to reach a consensus among different sectors on the essential issues of the territorial development in Cartagena, according to previous experience developed [30].

This work is divided in five principal sections. In the first one, a brief exposition of the related literature found is presented. In the following one, the methodological process is described. In the next two sections, a detailed description of the case study is presented, explaining the steps and results of the construction and application of the decision-making model through the ANP. Finally, conclusions and the challenges posed by this work are included.

\section{Literature Review}

Several authors introduced the use of MCDM techniques for Sustainability Assessment [31]. Many of them focused on the use of the Analytic Hierarchy Process (AHP) [32], which has been accepted as a leading multi-criteria decision model due to its ease of use for preferential information elicitation from expert subjects [33-37] to assign priorities to the criteria or indicators involved in the problem. However, AHP does not allow considering the interdependences among criteria. For this reason, the use of the Analytic Network Process (ANP) is proposed because it allows for better representing the complex interactions among the different components of a real system [38,39], as is the case in the field of sustainable evaluation.

The ANP procedure, a method developed by Saaty [40] to generalize his original AHP, provides a framework to address decision making or problem assessment. It allows for more complex, interdependent and feedback relationships between the elements of a hierarchy [41], thus avoiding the compensation problem of other models [42]. It constitutes a problem in a structure or network system composed of different elements (criteria and alternatives), grouped in clusters and connected to each other in any possible way. The network provides a more accurate modeling of complex environments and allows for handling the usual situation of interdependence between elements in sustainable planning scenarios [43-45]. In this work, interdependence among the different criteria of the evaluation model has been determined in collaboration with the experts (Table 2).

Regarding the nautical and naval sector, Kovačić [29], in his work on the location of a nautical tourism port, mentions the shortage of publications in which the relevant factors for location selection and installation of nautical infrastructures are analyzed, due to the complexity of its development and the economic effects generated. 
An important part of the work regarding the use of MCDM methods for planning in the maritime industry (nautical and naval) is related to selecting places for new structures' locations. This includes: selecting the location of a nautical tourism port [29]; selecting sites for dry ports [46]; selecting a cruise port of call location [47]; assessing coastal reclamation suitability [48]; and strategies selection for risk mitigation associated with offshore wind parks [49].

The use of AHP in this sector includes the capacity evaluation of several ports for the location of a port facility [37]; planning of a transport infrastructure [50]; and the selection of the location for the construction of a marina [19].

Some recent applications of ANP to the field of sustainable development are found in strategic policy planning [42,51,52]; evaluation of strategies for urban sustainable planning [53]; environmental assessment tools of sustainability strategies [30,54]; development of an indicator system for measuring the social sustainability [45]; environmental pressure assessment [55]; sustainable tourism development [56]; sustainable forest management [57]; regional sustainability assessment [43]; or sustainable development of housing communities [58].

Evidence regarding the use of ANP for the evaluation of strategies to improve the nautical and naval industry has not been found. No ANP applications were located in the consulted sources, regarding the concepts of marine spatial planning, coastal and/or marine location planning, environmental site selection or Integrated Coastal Zone Management (ICZM).

The use of ANP in the sector of interest was found in the work developed by Pourebrahim et al. [59] considered as the first work in which this technique is used for criteria selection to guarantee sustainability in the planning of coastal land use. Beside Hasanzadeh et al. [60,61] and Najafinasab et al. [62] ANP has been used in criteria identification and prioritization for the selection of sites for wharfs locations to prioritize the most convenient location for crude oil docks: and with the objective of selecting and integrating criteria regarding the planning of the use of land in coastal zones.

\section{Methodology}

The methodological proposal is based on the ANP procedure developed by Saaty [40]. The model comprises the following steps:

1. Identifying the components and elements of the network and their relationships.

2. Conducting pairwise comparisons of the elements.

3. Placing the resulting relative importance weights (eigenvectors) in pairwise comparison matrices within the matrix (unweighted matrix).

4. Conducting pairwise comparisons of the clusters.

5. Weighting the blocks of the unweighted matrix, by the corresponding priorities of the clusters, so that it can be column-stochastic (weighted matrix).

6. Raising the weighted matrix to limiting powers until the weights converge and remain stable (limit matrix).

7. Obtain the elements' prioritizations according to any of the columns of the limit matrix.

8. Once the results are obtained, in case some alternatives achieve very similar results, a sensitivity analysis should be carried out in order to demonstrate the robustness of the ranking obtained.

Following the route suggested by the technique, the procedure proposal shown in Figure 1 was designed. First, the problem of the Cartagena's nautical and naval sector was analyzed, defining the objective to be achieved. Then, on the basis of the local and national plans posed to strengthen the sector, the alternatives to be considered in the model were selected. The criteria were identified through a literature review, revised by an expert. Once criteria, clusters and strategies were defined, the ANP model was designed for evaluation.

Afterwards, experts were selected on the basis of their profile and knowledge about the sector, and contacted. The experts performed the pairwise comparison between criteria and alternatives, following the ANP procedure, through the questionnaire designed by the facilitators. In the following stage, 
calculations related with the weight of each criterion and alternative prioritization were performed. The results were obtained through the individual judgements issued by the experts, which were aggregated using the geometric mean, as suggested by Saaty [40]. Once the final results were obtained, the facilitators informed the experts about the individual and global results.

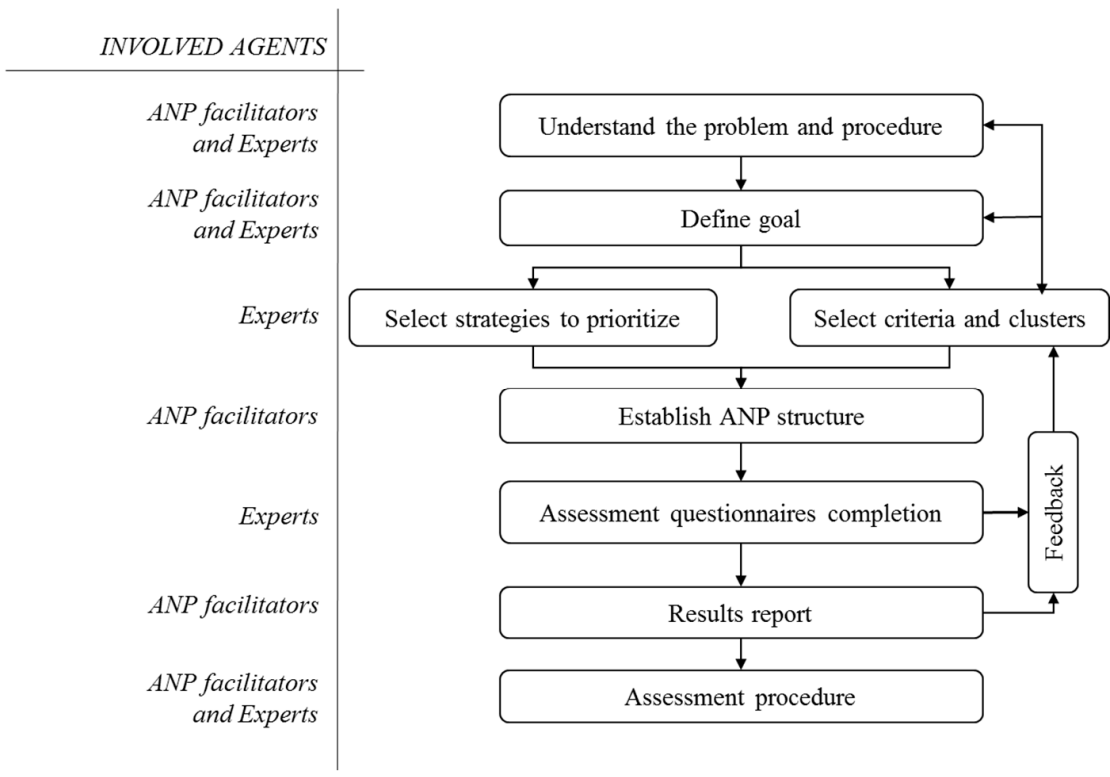

Figure 1. Methodology flow chart.

\section{Case Study: Nautical and Naval Industries in Cartagena de Indias, Colombia}

In order to demonstrate its proper functioning, the present methodology has been applied to the case study of the nautical and naval sector in Cartagena de Indias. This city, located in the South Caribbean zone, has good morphologic and geographic conditions, so its bay represents a strategic point for the northern Colombian economy [15]. The city is the leader in the Colombian nautical sector, concentrating the broadest offer in nautical facilities as well as vessel and nautical recreational related services [63]. Furthermore, its shipbuilding industry is renowned in the Caribbean basin, and it has been designated as a "producer of high strategic value innovative products" [64].

For several years, the city has been exercising long-term planning, in which a unified regional vision is defined through the development of strategic sectors and transversal factors. In this plan, the city defines its vocation and focuses its efforts on achieving productive transformation and increasing its competitiveness through recognized economic development potentials, such as tourism, logistic and transportation for foreign trade, petrochemical-plastic production and the design, construction and vessel repair industry [16]. This last industry is recognized as the city's most recent and growing industry.

The nautical cluster is essentially related to companies, which directly or indirectly offer leisure services or recreational activities in small vessels with an average length of $25 \mathrm{~m}$. These vessels are sailboats, yachts or boats. The naval cluster is focused on big vessels, with a commercial or military profile [63]. Both clusters are born from the city's port vocation, so a close relationship exists between them. Many of the associated services are overlapped because they are included in the so-called naval, maritime, fluvial and port industries, and they are promoted by almost the same support institutions. Thus, in this work, beyond separating the clusters, it is considered that, by supporting one, both are being fostered.

For many years, the sector has been promoting the location, construction and consolidation of shipyards for military, commercial and nautical tourism vessels. These efforts have been reflected in the increase of the number of companies dedicated to vessels construction and repair [64], in 
recreational/sports vessels registration in Cartagena (Colombian Maritime Authority: Dirección General Marítima DIMAR) and in the request for permits to construct new nautical facilities (marinas, marina-shipyard-boatyard MSBs, dry marinas, nautical clubs and docks and shipyards). The new nautical facilities are the most controversial issue among the different city sectors because they are projects for construction in zones owned by the Nation. These zones are either located along the coast (Figure 2) close to residential and high commercial flow zones or they will affect the natural value and scenic beauty of some areas. As mentioned by Petrosillo et al. [3] and Freeman, Whiting and Kelly [18], the increase in these activities will boost the conflict potential between activities that compete for the same scarce resources and/or coastal spaces.

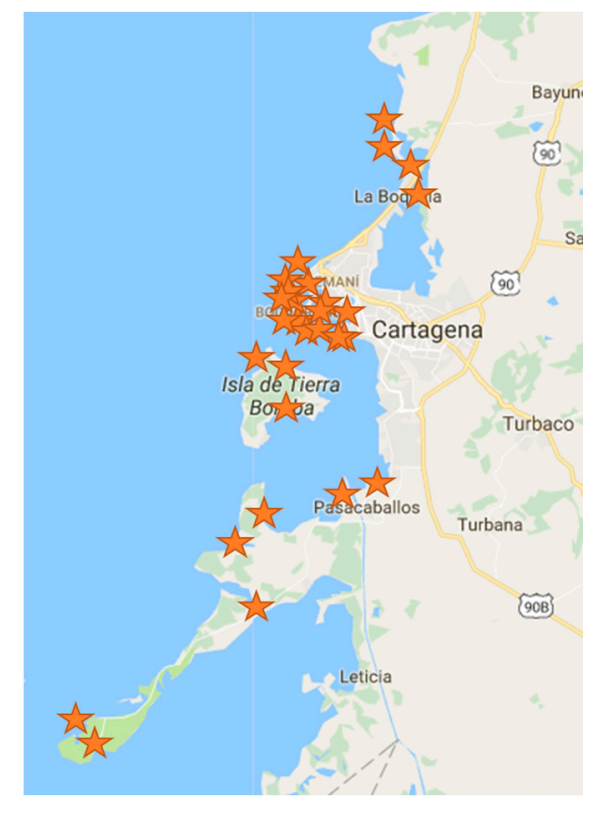

Figure 2. Zones requested for marinas location. Adapted from Google Maps.

For the previously mentioned reasons, this work aims to support decision making in order to determine where the nautical development pole should be located, that is to say, which zone is the most suitable for the location of the new nautical facilities.

A detailed description or the methodology implementation is shown below.

\subsection{Experts Selection}

This work has been developed in collaboration with the private sector in order to present to the public sector a relevant and useful tool to reach a consensus among different stakeholders involved in a controversial issue related to the expansion of nautical facilities. Thus, we will consider the academic expert as representative of the public sector, as a first approach. The first one is a local businessman, who leads some initiatives to strengthen the sector. He is also a member of the regional University-Business-State Committee as well as of the board of directors of the Nautical Association of Colombia. This expert will represent the private sector, as main financers and promoters of the strategies, which will be prioritized. Representing the academic sector of the city, the second expert was a member of the Naval Engineering Master degree in the Colombian Naval School, who has research experience in aspects related.

\subsection{Strategies Selection}

In order to define development strategies, a review of local and national plans and programs designed to strengthen the sector was performed. Some of the consulted documents were: Plan Regional 
de Competitividad Cartagena y Bolívar 2008-2032 [16]; Plan de Desarrollo Local 2016-2019 [65]; Plan Sectorial de Turismo de Cartagena de Indias 2014-2017 [66]; and Plan Nacional de Turismo Náutico de Colombia 2012 [17], among others.

Four proposals (alternatives) were selected, oriented to the definition of the most appropriate area to locate nautical and naval development zones in the city (Figure 3). Prioritizing the considered zones should allow channeling most of this sector's development and should help solving the approval status of many of the requests submitted to the competent authorities. The alternatives are:

Alternative 1 (A1). Construction of a Civic External Marina: this facility would be placed offshore with the aim of reducing its impact in the historical center surroundings and circumvent the limitations of the Historical Center and Influence Zones Management and Protection Plan. This alternative can be considered together with another development initiative contemplated for the same area.

Alternative 2 (A2). Construction of a Civic Internal Marina: Located in the Bay interior, between the zones where the city's touristic dock currently stands and the entrance of the main hotel area (Bocagrande). This option would minimize the impact on landscape, although it requires resizing the available coastline. The advantage of this alternative compared to the External Marina alternative is its cost and the arrangement and integration in a singular and leisure manner of the Muelle de la Bodeguita and the Naval Base of the city.

Alternative 3 (A3). Design of a network of marinas, docks and nautical bases in zones of the city to be recovered: To constitute a network of marinas and zones for nautical and naval development in water bodies and internal spaces of the city to be recovered (Bazurto and Ciénega de las Quintas, Ciénaga de la Virgen). This alternative promotes the recovery of urban spaces, diminishing concentration in very densely populated zones of the city.

Alternative 4 (A4). Design of a network of marinas, docks and nautical bases in the insular districts of the city: Construction of different nautical and naval facilities in the insular districts of the city. This alternative decreases concentration in the urban center and enables its future expansion. This option would minimize the landscape impact and would foster development in other zones.

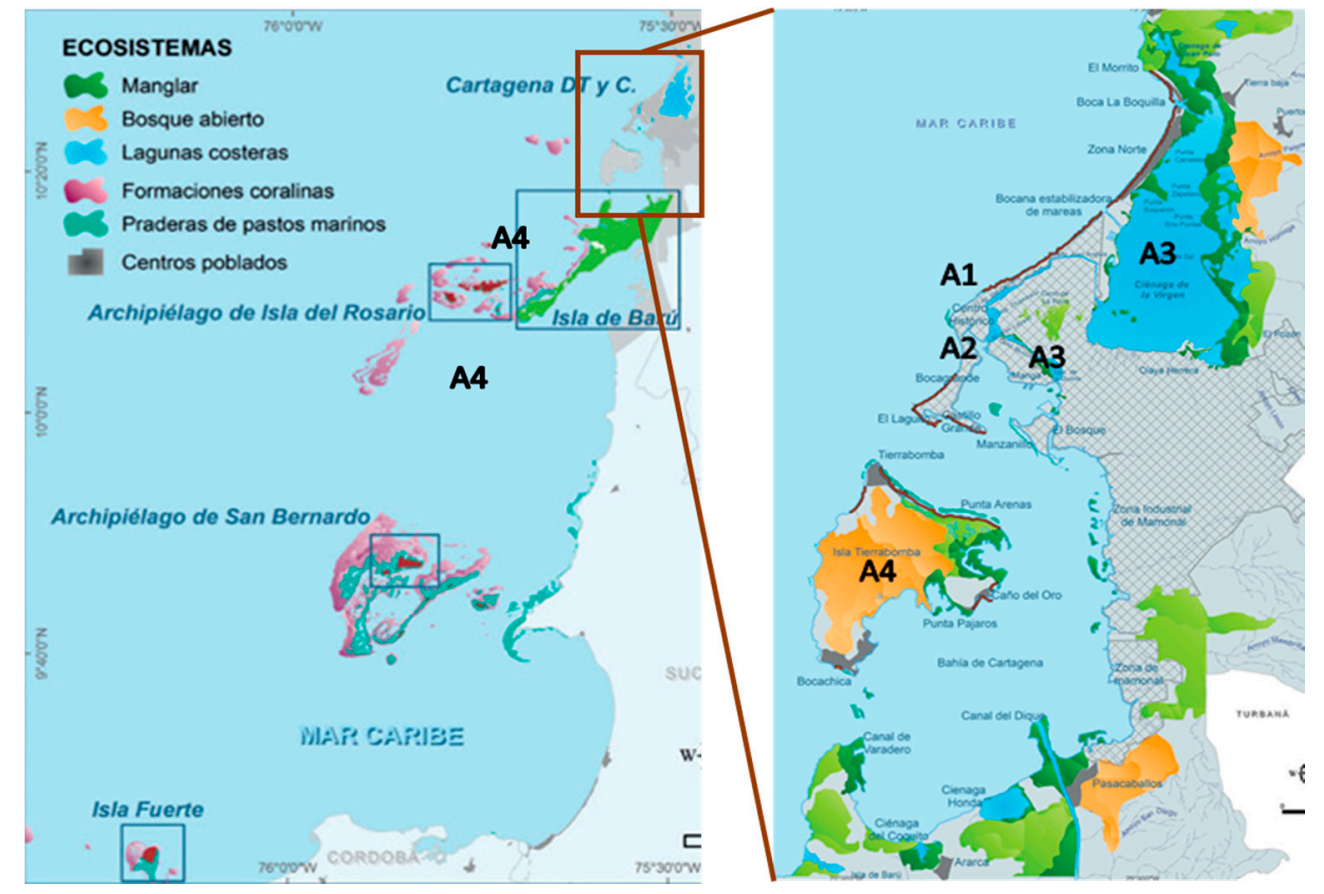

Figure 3. Location areas proposed by the alternatives (adapted from: Plan 4C Cartagena Competitiva y Compatible con el Clima). 


\subsection{Selection of Sustainability Criteria}

Criteria that could influence the sustainable evaluation of the proposed alternatives were identified. It was necessary to make sure that these criteria could be grouped, that they were relevant, not redundant and easy to understand for the different actors.

The final list of 14 criteria grouped in four evaluation clusters (Table 1) was defined on the basis of a bibliographic review and with the assistance of one of the experts.

Table 1. Criteria and clusters.

\begin{tabular}{|c|c|c|c|}
\hline Cluster & Definition & Criteria & Definition \\
\hline \multirow{4}{*}{ Environmental } & \multirow{4}{*}{$\begin{array}{l}\text { Group criteria aimed at } \\
\text { assessing the } \\
\text { relationship between } \\
\text { alternatives considered } \\
\text { and the environment. }\end{array}$} & $\begin{array}{l}\text { C1.1 Use of natural } \\
\text { spaces and material } \\
\text { heritage. }\end{array}$ & $\begin{array}{l}\text { Use of natural areas and tangible assets of } \\
\text { the city, mainly those considered heritage. }\end{array}$ \\
\hline & & $\begin{array}{l}\text { C1.2 Environmental risks } \\
\text { and threats. }\end{array}$ & $\begin{array}{l}\text { Environmental risk level associated with } \\
\text { alternatives, such as: coastal erosion, sea } \\
\text { level rise, sea swells, floods. }\end{array}$ \\
\hline & & $\begin{array}{l}\text { C1.3 Environmental } \\
\text { impact. }\end{array}$ & $\begin{array}{l}\text { Considers the use of mangroves, water } \\
\text { removal, solid waste production and } \\
\text { people agglomeration. }\end{array}$ \\
\hline & & $\begin{array}{l}\text { C1.4 Water and } \\
\text { soil quality. }\end{array}$ & $\begin{array}{l}\text { Water quality of the main water body to be } \\
\text { affected, and of the considered terrain. }\end{array}$ \\
\hline \multirow{4}{*}{ Sociocultural } & \multirow{4}{*}{$\begin{array}{l}\text { Assesses alternatives } \\
\text { impact on the city's } \\
\text { inhabitants. }\end{array}$} & C2.1 Urban density. & $\begin{array}{l}\text { Urban, commercial and industrial } \\
\text { settlements concentration in the area. }\end{array}$ \\
\hline & & $\begin{array}{l}\text { C2.2 Generated urban } \\
\text { renovation. }\end{array}$ & $\begin{array}{l}\text { Possibility to generate urban renovation } \\
\text { and recovery of spaces required by the city. }\end{array}$ \\
\hline & & $\begin{array}{l}\text { C2.3 Population } \\
\text { acceptance. }\end{array}$ & $\begin{array}{l}\text { Compatibility between the inhabitants of } \\
\text { the zone to be impacted and the considered } \\
\text { alternative. }\end{array}$ \\
\hline & & $\begin{array}{l}\text { C2.4 Impact on the } \\
\text { quality of life of the } \\
\text { population. }\end{array}$ & $\begin{array}{l}\text { Impact on the quality of life of citizens } \\
\text { in general. }\end{array}$ \\
\hline \multirow{4}{*}{ Economic } & \multirow{4}{*}{$\begin{array}{l}\text { It relates the potential } \\
\text { activities to be } \\
\text { performed to the } \\
\text { city economy. }\end{array}$} & $\begin{array}{l}\text { C3.1 Promotion of other } \\
\text { economic activities. }\end{array}$ & $\begin{array}{l}\text { Relationship with other sectors of the } \\
\text { city's economy. }\end{array}$ \\
\hline & & C3.2 Expansion capacity. & Possibilities of long-term expansion. \\
\hline & & $\begin{array}{l}\text { C3.3 Public-private } \\
\text { necessary investments. }\end{array}$ & $\begin{array}{l}\text { Investment required for the alternatives } \\
\text { launching. }\end{array}$ \\
\hline & & $\begin{array}{l}\text { C3.4 Connectivity with } \\
\text { the rest of the city. }\end{array}$ & Connection with the rest of the city. \\
\hline \multirow[t]{2}{*}{ Political } & \multirow{2}{*}{$\begin{array}{l}\text { Association with the } \\
\text { city's dispositions } \\
\text { and plans. }\end{array}$} & $\begin{array}{l}\text { C4.1 Compatibility with } \\
\text { land-use planning and } \\
\text { existing regulations. }\end{array}$ & $\begin{array}{l}\text { Affinity of each alternative with land-use } \\
\text { planning over the potential areas to be used } \\
\text { by each alternative. }\end{array}$ \\
\hline & & $\begin{array}{l}\text { C4.2 Compatibility with } \\
\text { local plans and other } \\
\text { strategic initiatives of the } \\
\text { city and the region. }\end{array}$ & $\begin{array}{l}\text { Affinity of each alternative with policies, } \\
\text { plans, projects and/or local, departmental } \\
\text { and national existing programs. }\end{array}$ \\
\hline
\end{tabular}

\subsection{Structure of the Decision Problem}

After the identification of the model elements, influences among them were determined using a relationship matrix (Table 2), where 1 means that the file element influences the column element and 0 means that there is no influence among them.

The proposed ANP evaluation model is illustrated by the network shown in Figure 4. The bidirectional arrows indicate influences between clusters in both directions. That is to say, the elements in a cluster (i) exert some influence over elements in another cluster (j). Feedback means that there is influence between criteria belonging to the same group. 
Table 2. Influence matrix.

\begin{tabular}{ccccccccccccccccccc}
\hline & $\mathbf{1 . 1}$ & $\mathbf{1 . 2}$ & $\mathbf{1 . 3}$ & $\mathbf{1 . 4}$ & $\mathbf{2 . 1}$ & $\mathbf{2 . 2}$ & $\mathbf{2 . 3}$ & $\mathbf{2 . 4}$ & $\mathbf{3 . 1}$ & $\mathbf{3 . 2}$ & $\mathbf{3 . 3}$ & $\mathbf{3 . 4}$ & $\mathbf{4 . 1}$ & $\mathbf{4 . 2}$ & A1 & A2 & A3 & A4 \\
\hline 1.1 & 0 & 1 & 1 & 1 & 0 & 1 & 1 & 0 & 0 & 1 & 1 & 0 & 0 & 1 & 1 & 1 & 1 & 1 \\
1.2 & 1 & 0 & 1 & 0 & 0 & 0 & 1 & 1 & 0 & 1 & 1 & 0 & 1 & 0 & 1 & 1 & 1 & 1 \\
1.3 & 0 & 1 & 0 & 1 & 0 & 0 & 1 & 1 & 0 & 1 & 0 & 0 & 0 & 0 & 1 & 1 & 1 & 1 \\
1.4 & 1 & 1 & 1 & 0 & 0 & 1 & 0 & 0 & 0 & 1 & 1 & 0 & 0 & 0 & 1 & 1 & 1 & 1 \\
2.1 & 1 & 1 & 1 & 1 & 0 & 1 & 1 & 1 & 1 & 1 & 1 & 1 & 1 & 0 & 1 & 1 & 1 & 1 \\
2.2 & 0 & 0 & 0 & 0 & 0 & 0 & 1 & 1 & 0 & 0 & 0 & 0 & 0 & 0 & 1 & 1 & 1 & 1 \\
2.3 & 1 & 0 & 0 & 0 & 0 & 0 & 0 & 1 & 0 & 1 & 0 & 0 & 0 & 0 & 1 & 1 & 1 & 1 \\
2.4 & 1 & 0 & 0 & 0 & 0 & 0 & 1 & 0 & 0 & 0 & 0 & 0 & 0 & 0 & 1 & 1 & 1 & 1 \\
3.1 & 1 & 0 & 0 & 0 & 0 & 0 & 1 & 1 & 0 & 1 & 0 & 0 & 0 & 1 & 1 & 1 & 1 & 1 \\
3.2 & 1 & 0 & 1 & 0 & 0 & 0 & 0 & 0 & 1 & 0 & 0 & 0 & 0 & 1 & 1 & 1 & 1 & 1 \\
3.3 & 1 & 0 & 0 & 0 & 0 & 1 & 0 & 0 & 0 & 0 & 0 & 0 & 0 & 1 & 1 & 1 & 1 & 1 \\
3.4 & 1 & 0 & 0 & 0 & 0 & 0 & 1 & 1 & 1 & 1 & 1 & 0 & 0 & 1 & 1 & 1 & 1 & 1 \\
4.1 & 1 & 0 & 0 & 0 & 1 & 1 & 1 & 0 & 0 & 1 & 1 & 0 & 0 & 1 & 1 & 1 & 1 & 1 \\
4.2 & 1 & 0 & 0 & 0 & 0 & 1 & 1 & 0 & 1 & 1 & 1 & 0 & 0 & 0 & 1 & 1 & 1 & 1 \\
A1 & 1 & 1 & 1 & 1 & 1 & 1 & 1 & 1 & 1 & 1 & 1 & 1 & 1 & 1 & 0 & 0 & 0 & 0 \\
A2 & 1 & 1 & 1 & 1 & 1 & 1 & 1 & 1 & 1 & 1 & 1 & 1 & 1 & 1 & 0 & 0 & 0 & 0 \\
A3 & 1 & 1 & 1 & 1 & 1 & 1 & 1 & 1 & 1 & 1 & 1 & 1 & 1 & 1 & 0 & 0 & 0 & 0 \\
A4 & 1 & 1 & 1 & 1 & 1 & 1 & 1 & 1 & 1 & 1 & 1 & 1 & 1 & 1 & 0 & 0 & 0 & 0 \\
\hline
\end{tabular}

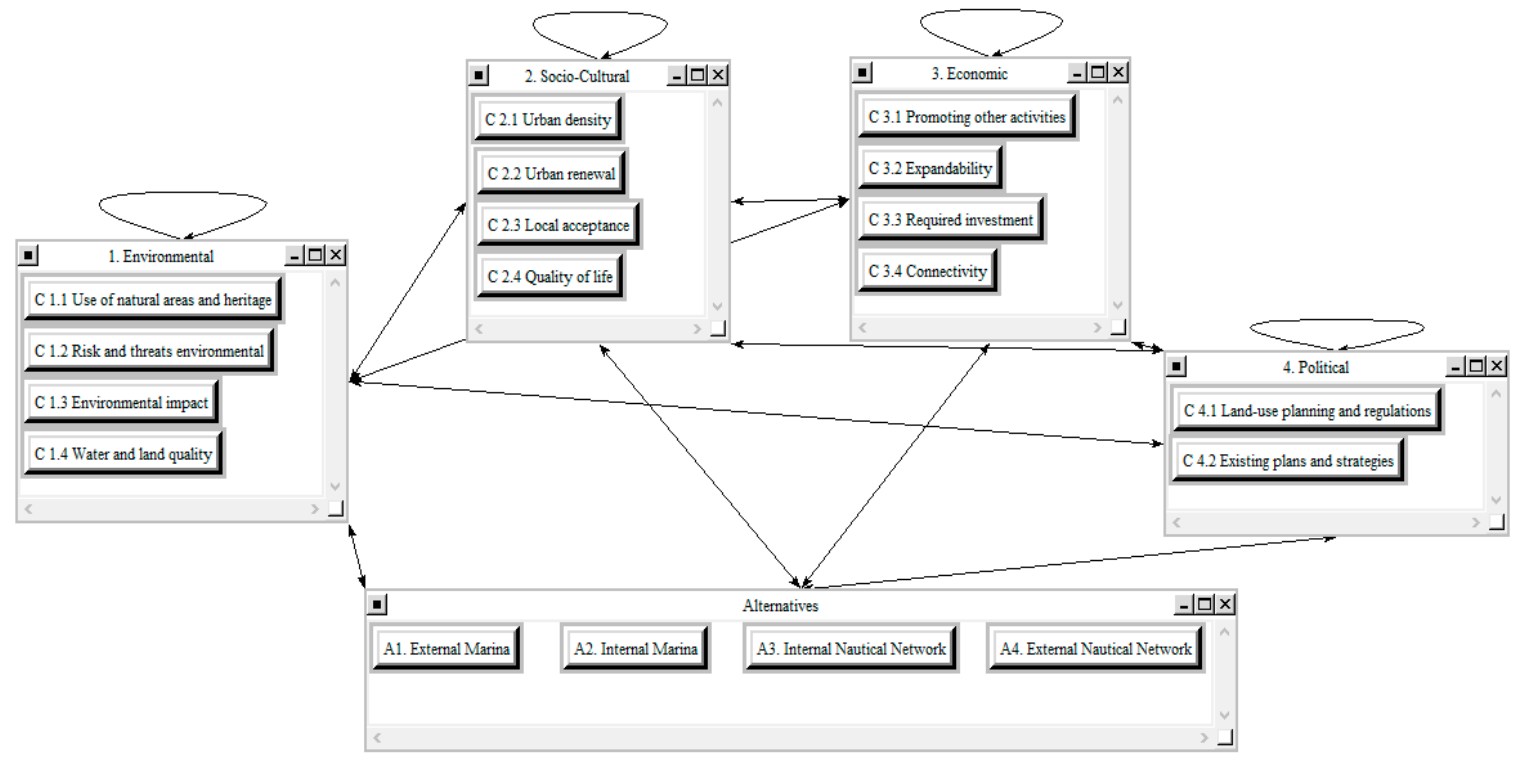

Figure 4. Analytic Network Process ANP network model of the case study.

\subsection{Application of ANP}

Once the influences among the model elements are determined, a questionnaire was designed with the aim of determining a compliance index of the model objective for each alternative with regard to all considered criteria. This information was collected from the experts through a questionnaire designed to allow pairwise comparisons. Figure 5 shows an example of a question posed for the criteria analysis.

All of the calculations were performed using the SuperDecision( $\odot$ v.2.0.8 software (Creative Decisions Foundation, Pittsburgh, PA, USA). Once all pairwise comparisons matrixes were completed, a limit supermatrix was obtained. The results correspond to the global judgements. Judgement aggregation was performed using the geometric mean [40]. 
In your opinion, which of the two criteria sets (clusters) contributes more to improve the nautical and naval sector of the city of Cartagena? Place an $\mathrm{X}$ where appropriate.

\begin{tabular}{|c|c|c|c|c|c|c|c|c|c|c|c|c|c|c|c|c|c|c|}
\hline & 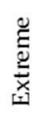 & & $\stackrel{\frac{0}{0}}{>} \frac{0}{\infty}$ & & $\begin{array}{l}0 \\
\frac{3}{0} \\
\frac{3}{\omega}\end{array}$ & & 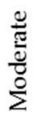 & & $\underset{\widetilde{g}}{\bar{\Xi}}$ & & 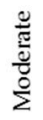 & & $\frac{60}{3}$ & & $\stackrel{\frac{2}{0}}{>} \frac{0}{0}$ & & 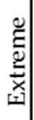 & \\
\hline Environmental & 9 & 8 & 7 & 6 & $x$ & 4 & 3 & 2 & 1 & 2 & 3 & 4 & 5 & 6 & 7 & 8 & 9 & Socio cultural \\
\hline
\end{tabular}

The answer in this example means that: it is considered the set of environmental criteria contributes strongly (5) more than the sociocultural criteria set in improving the nautical and naval sector of the city of Cartagena.

Figure 5. Example of a question used for the ANP questionnaire.

\section{Results}

There is a high degree of concordance among the experts' assessments, so the results can be evaluated as a whole. The existence of these close positions among the experts is a good sign for the sector because they can be a good starting point to obtain wider consensus. Thus, results will be globally analyzed, initially for criteria and then for strategies.

\subsection{Results Obtained for the Criteria}

The final limit matrix shows the obtained priority for each criterion, a non-dimensional value that can be considered as their relative importance. Results show (Table 3 and Figure 6) that, altogether, most valued clusters were the environmental (0.37) and the sociocultural (0.30) ones. The less valued cluster is the economic one (0.14).

Table 3. Cluster and criteria relative importance.

\begin{tabular}{lclc}
\hline \multicolumn{1}{c}{ Cluster } & Importance & \multicolumn{1}{c}{ Criteria } & Importance \\
\hline \multirow{3}{*}{ 1. Environmental } & \multirow{3}{*}{0.374} & C1.1 Use of natural areas and heritage & 0.114 \\
& & C1.2 Environmental risks and threats & 0.119 \\
& & C1.3 Environmental impact & 0.088 \\
& & C1.4 Water and land quality & 0.054 \\
\hline \multirow{2}{*}{ 2. Sociocultural } & \multirow{2}{*}{0.297} & C2.1 Urban density & 0.217 \\
& & C2.2 Urban renewal & 0.037 \\
& & C2.3 Local acceptance & 0.017 \\
3. Economic & \multirow{2}{*}{0.138} & C 2.4 Quality of life & 0.027 \\
& & C3.1 Promoting other activities & 0.042 \\
& & C3.2 Expandability & 0.055 \\
4. Political & \multirow{2}{*}{0.190} & C3.4 Connectivity & 0.019 \\
& & C4.1 Land-use planning and regulations & 0.022 \\
\hline
\end{tabular}

In concordance with the results by cluster, the global results for each criteria show that the most important is C2.1 Urban density (0.22); followed by C4.1 Land-use planning and regulations (0.16). Subsequently, criterion C1.2 Environmental risk and threats (0.12), C1.1 Use of natural areas and heritage (0.11) and C1.3 Environmental impact (0.09) show an intermediate value. The least valued criteria are C2.3 Local acceptance (0.02), C3.3 Required investment (0.02) and C3.4 Connectivity (0.02).

The low evaluation of the economic criteria is noteworthy, especially the one related to the required investment. This can be explained due to the closeness among the estimated costs of the alternatives and also because the projects for the construction of new nautical facilities are already designed, and they are just waiting for the approval from the competent authorities. Thus, beyond the economic costs and benefits associated with each alternative, results show a greater interest for the environmental effects, good or bad, that the considered strategies can have over the city's water 
bodies; and the current capacity of the city to accommodate these new initiatives. As stated above, the new infrastructure requests' purposes are directed to zones of high urban and commercial density, and this directly affects other aspects such as the local acceptance or the population life quality.

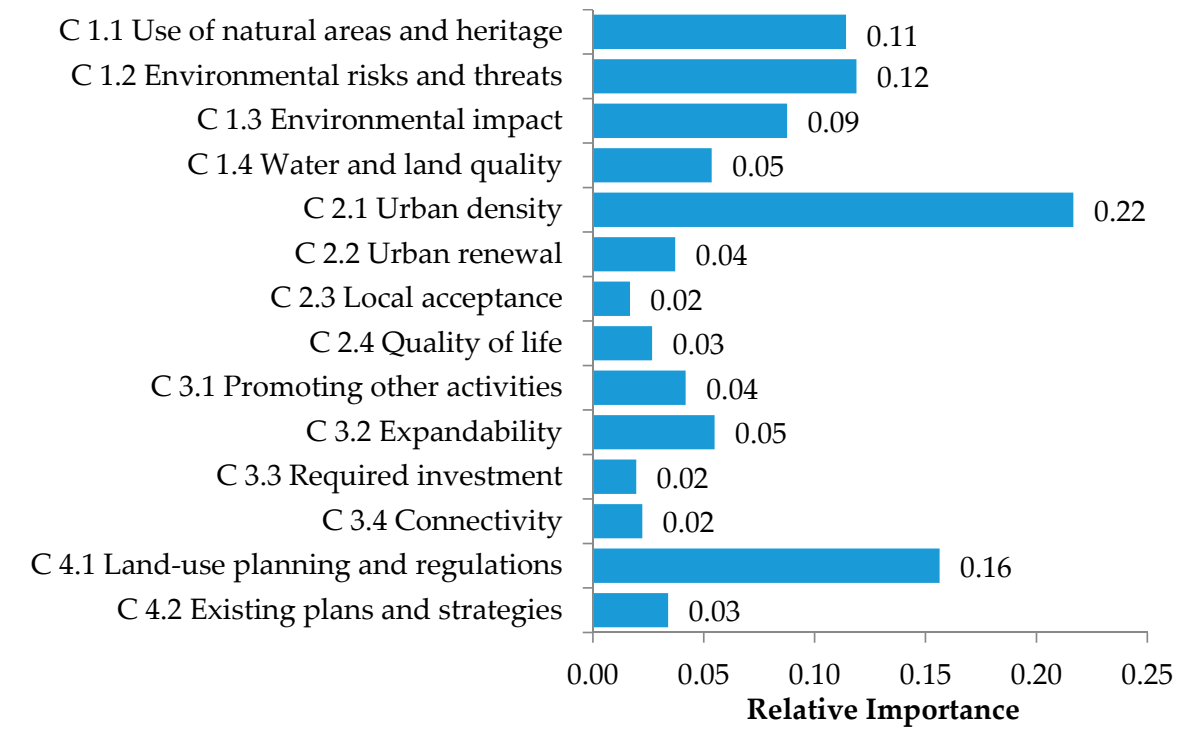

Figure 6. Results for the criteria.

\subsection{Results Obtained for the Alternatives}

The final objective of this work is to establish a priority for each alternative. The results obtained for the analyzed development strategies are shown in Figure 7. Priorities obtained for the alternatives can be considered as their Preference Index, so the higher this index value, the better the proposal prioritization will be. Concordance in the assessment of the relative importance among the two experts is maintained so, considering the closeness between their answers, the results will continue to be globally analyzed.

Results indicate that the best strategy to be implemented to improve the nautical and naval sector in the city of Cartagena is the A4. External Nautical Network (39\%), followed by A3. Internal Nautical Network (30\%) and A1. External Marina (24\%). The Alternative A2. Internal Marina ( $7 \%$ ) is the less valued by far.

These results are coherent with the weights assigned to the criteria. The proposal A4. Design of a network of marinas, docks and nautical bases in the insular districts of the city has been positively valued due to the importance assigned to the criterion related to urban density. Thanks to this external location and the construction of different nautical and naval facilities in several zones, the future expansion of these activities could be enabled, avoiding the concentration of nautical and naval activities in a single geographical area. The fact that this alternative must also consider the importance of land-use planning in the insular zone is relevant. This factor must be strongly labored by the city, and it is reflected in the importance of the criterion related to compatibility with land-use planning and regulations.

Altogether, the environmental criteria received a good valuation, thus the alternative A3. Design of a network of marinas, docks and nautical bases in zones of the city to be recovered also received a good valuation. This is due to the generalized awareness that some of the city's water bodies are currently highly contaminated and it is important to recover them. These water bodies are located in zones that must be recovered by the city, so this also benefits the urban density criterion.

Alternative A1. Construction of a Civic External Marina also received a good assessment due to the density criterion, to its integration with other initiatives and the possibility of its closeness with the city's historic heritage. 
Finally, regarding the alternative A2. Construction of a Civic Internal Marina, despite its main advantage being its cost, it has received the lower valuation probably because the zone in which this alternative would be located is a site considered as not feasible. This site has been involved in some disputes regarding its property and its compatibility for certain uses.

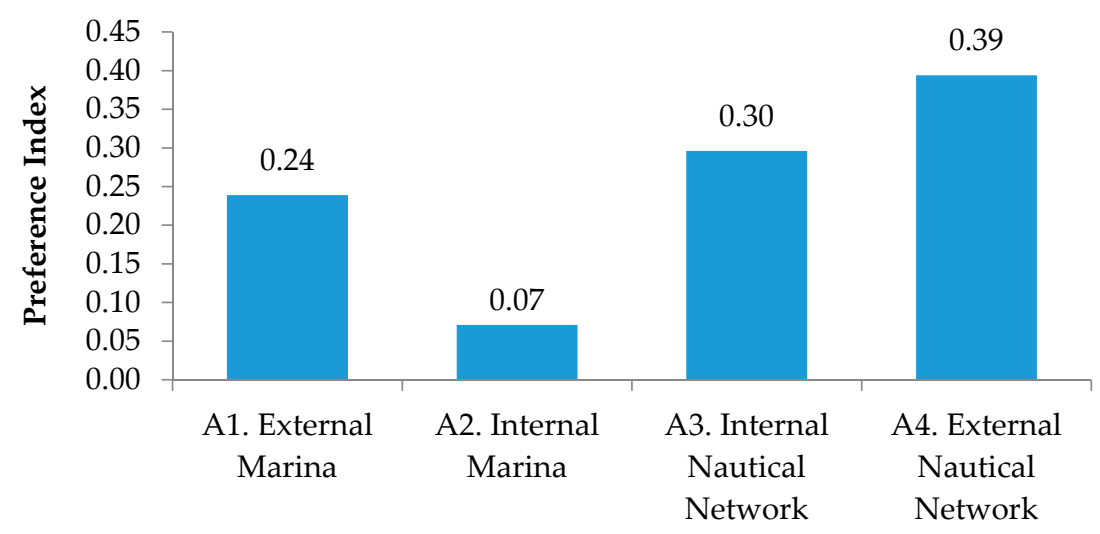

Figure 7. Results for the alternatives.

\section{Discussion}

Through the use of ANP for prioritizing the Cartagena nautical and naval strategic plans, some conclusions are reached concerning both the results and the appropriateness of the methodology itself.

The results obtained with the model allow concluding that beyond the economic aspects, there is concern over the environmental effects the alternatives could produce, or the way in which they could benefit the current conditions of some water bodies. Furthermore, to answer certain demands of the general population is considered to be very important-for example, the issues that most affect their everyday life and indirectly represent an improvement of their quality of life. In this case, it is specifically the generalized need to diminish the concentration of new urban developments on certain areas of the city. In general, the results practically exclude the alternative A2. Construction of a Civic Internal Marina.

The technique ANP used allowed for obtaining an agreement on the final assessment of the alternatives, where the highest valuation was obtained by alternative A4. Design of a network of marinas, docks and nautical bases in the insular districts of the city, and the lowest valuation was obtained by alternative A2. Construction of a Civic Internal Marina. The results maintain a coherence with the importance assigned to some elements of the model. Thus, the better valued alternatives are those that least affect the urban density of certain zones of the city and those which potentially provide higher environmental benefits for the city.

Concerning the use of ANP as a tool for prioritization of strategic plans, we can conclude that it allowed transparency and participation of the stakeholders. There is not a maximum or minimum number of stakeholders required. Experts involved have to be interested and have knowledge about the decision problem. In addition, they have to be willing to answer the questionnaires because they might be very time-consuming.

The ANP procedure becomes not only interesting in terms of reaching final prioritization but also in terms of enabling reflection on the subject. Both stakeholders felt that the ANP procedure has allowed them to deal with prioritization in an organized and systematic way.

The ANP is a good tool for the sector managers because it facilitates the prioritizing process of strategic plans. This procedure allows for naval and nautical achieving an agreement among experts in an organized and systematic manner, thus it can be adopted and applied to other types of decisions. Considering also the closeness between participants' answers, achieving consensus in the nautical and naval sector can be a good starting point. 
Different actors perceive estrangement between the city's inhabitants and the nautical and naval sector, thus it is worth noting that the involved parties must work towards the generation of a nautical culture in the city and promote the generation of knowledge about the sector, in order to motivate a rapprochement of both sides.

As future lines to be developed, we suggest involving more experts. However, to avoid ambiguities in the process, other expert selection tools could be considered, such as Stakeholder Analysis and Social Network Analysis (SNA). In this way, only key decision makers would be involved. Moreover, if the model is to be used as a prioritization tool of other strategic plans, such as plans for development of different strategic sectors of Cartagena, the experts, criteria and alternatives would have to be adapted to the new scenario.

Furthermore, a combination of ANP with geospatial analysis can be also considered to support the decision making process. As the information found on this topic concludes, the Geographic Information Systems (GIS) are widely accepted and they can provide mapping parameters that characterize the earth's surface, improving the decision process.

The uncertainties in climate change predictions and the local scale risks at which the city is exposed could also be considered in the long-term planning and regulation processes of the coastal and marine space, in contrast with other economic sectors of the city, the central interest of which is also the utilization of the coast and can also be affected by climate change. Concerning the utility and applicability of this tool to similar cases, the procedure is easy to adapt to other strategic sectors of the city as long as experts and the evaluation criteria are accurately selected.

Acknowledgments: The authors would like to thank the "Bolívar Gana con Ciencia" project from the Gobernación de Bolívar (Colombia) for the financial support. Special thanks are also extended to the experts for their enthusiastic cooperation, which made this study possible.

Author Contributions: This research was conducted by Hannia Gonzalez-Urango under the supervision of Monica Garcia-Melon, who designed the research, provided technical support and guidance, and directly contributed to the results of this article. Hannia Gonzalez-Urango wrote the paper under the supervision of Monica Garcia-Melon. Both authors have read and approved the final manuscript.

Conflicts of Interest: The authors declare no conflict of interest.

\section{References}

1. Iglesias-Campos, A.; Meiner, A.; Bowen, K.; Ansong, J.O. Coastal Population and Land Use Changes in Europe; Elsevier: Amsterdam, The Netherlands, 2015; pp. 29-49.

2. Cao, W.; Wong, M.H. Current status of coastal zone issues and management in China: A review. Environ. Int. 2007, 33, 985-992. [CrossRef] [PubMed]

3. Petrosillo, I.; Valente, D.; Zaccarelli, N.; Zurlini, G. Managing tourist harbors: Are managers aware of the real environmental risks? Mar. Pollut. Bull. 2009, 58, 1454-1461. [CrossRef] [PubMed]

4. Bulleri, F.; Chapman, M.G. The introduction of coastal infrastructure as a driver of change in marine environments. J. Appl. Ecol. 2010, 47, 26-35. [CrossRef]

5. Di Franco, A.; Graziano, M.; Franzitta, G.; Felline, S.; Chemello, R.; Milazzo, M. Do small marinas drive habitat specific impacts? A case study from Mediterranean Sea. Mar. Pollut. Bull. 2011, 62, 926-933. [CrossRef] [PubMed]

6. Sierra-Correa, P.C.; Cantera Kintz, J.R. Ecosystem-based adaptation for improving coastal planning for sea-level rise: A systematic review for mangrove coasts. Mar. Policy 2015, 51, 385-393. [CrossRef]

7. Baser, V.; Biyik, C. The problems and resolution approaches to land management in the coastal and maritime zones of Turkey. Ocean Coast. Manag. 2016, 119, 30-37. [CrossRef]

8. Papageorgiou, M. Coastal and marine tourism: A challenging factor in Marine Spatial Planning. Ocean Coast. Manag. 2016, 129, 44-48. [CrossRef]

9. European Commission. Communication from the Commission to The European Parliament, The Council, The European Economic and Social Committee and The Committee of the Regions: A European Strategy for More Growth and Jobs in Coastal and Maritime Tourism; European Commission: Brussels, Belgium, 2014. 
10. International Council of Marine Industry Associations ICOMIA. Recreational Boating Industry Statistics; Liquid Scope Limited: Surrey, UK, 2014.

11. Ho-Chun, I.; Cheng, F.; Incecik, A.; Carnie, P. Global Marine Trends 2030; Lloyd's Register Group Limited, QinetiQ and University of Strathclyde: London, UK, 2014.

12. Brida, J.G.; Pulina, M.; Riaño, E.; Zapata-Aguirre, S. Cruise passengers' experience embarking in a Caribbean home port. The case study of Cartagena de Indias. Ocean Coast. Manag. 2012, 55, 135-145. [CrossRef]

13. Ministerio de Comercio Industria y Turismo. Plan Nacional de Turismo Náutico de Colombia: Documento Ejecutivo General; GMN: Madrid, Spain, 2013. Available online: http:/ / asonauticacolombia.com/wp-content/ uploads /2015/09/plan-nacional-de-turismo-nautico-de-colombia-20131.pdf (accessed on 13 Febrary 2017).

14. Colombia Náutica. Colombia Nautica International Boat Show 2017; Colombia Náutica: Cartagena, Colombia, 2017; Available online: http:/ / colombianautica.co/acerca-de-colombia-nautica/ (accessed on 13 Febrary 2017).

15. Moreno-Egel, D.; Agámez, M.; Castro, E.; Voulgaris, G. Beach Morphology and Coastal Protection along Headland Bays in Cartagena de Indias, Colombia. J. Coast. Res. 2006, 2004, 1658-1664.

16. Comisión Regional de Competitividad de Cartagena y Bolívar. Plan Regional de Competitividad Cartagena y Bolivar 2008-2032; Cámara de Comercio de Cartagena: Cartagena, Colombia, 2010.

17. Ministerio de Comercio Industria y Turismo. Plan Nacional de Turismo Náutico de Colombia. Fase I: Análisis y Diagnóstico. Costa Caribe; GMN: Madrid, Spain, 2012. Available online: http:/ / www.mincit.gov.co/loader.php?1Servicio=Documentos\&lFuncion=verPdf\&id=64606\&name=4. _Estudio_de_Turismo_Nautico.pdf\&prefijo=file (accessed on 13 Febrary 2017).

18. Freeman, M.C.; Whiting, L.; Kelly, R.P. Assessing potential spatial and temporal conflicts in Washington's marine waters. Mar. Policy 2016, 70, 137-144. [CrossRef]

19. Gumusay, M.U.; Koseoglu, G.; Bakirman, T. An assessment of site suitability for marina construction in Istanbul, Turkey, using GIS and AHP multicriteria decision analysis. Environ. Monit. Assess. 2016. [CrossRef] [PubMed]

20. United Nations Economic Commission for Europe UNECE. Convention on Access To Information, Public Participation in Decision-Making and Access To Justice in Environmental Matters; United Nations Economic Commission for Europe UNECE: Aarhus, Denmark, 1998.

21. European Parliament and of the Council. European Parliament Directive 2003/4/EC; Official Journal of the European Union: Brussels, Belgium, 2003; Available online: http:/ /eur-lex.europa.eu/LexUriServ / LexUriServ.do?uri=OJ:L:2003:041:0026:0032:EN:PDF (accessed on 6 April 2017).

22. European Parliament and of the Council. European Parliament Directive 2003/35/EC; Official Journal of the European Union: Brussels, Belgium, 2003; Available online: http:/ / eur-lex.europa.eu/resource.html?uri= cellar:4a80a6c9-cdb3-4e27-a721-d5df1a0535bc.0004.02/DOC_1\&format=PDF (accessed on 6 April 2017).

23. Le Pira, M.; Ignaccolo, M.; Inturri, G.; Pluchino, A.; Rapisarda, A. Modelling stakeholder participation in transport planning. Case Stud. Transp. Policy 2016, 4, 230-238. [CrossRef]

24. Loken, E. Use of multicriteria decision analysis methods for energy planning problems. Renew. Sustain. Energy Rev. 2007, 11, 1584-1595. [CrossRef]

25. Berkes, F. From community-based resource management to complex systems: The scale issue and marine commons. Ecol. Soc. 2006, 11, 45. [CrossRef]

26. Domínguez-Tejo, E.; Metternicht, G.; Johnston, E.; Hedge, L. Marine Spatial planning advancing the ecosystem-based approach to coastal zone management: A review. Mar. Policy 2016, 72, 115-130. [CrossRef]

27. Izadikhah, M.; Saen, R.F. A new preference voting method for sustainable location planning using geographic information system and data envelopment analysis. J. Clean. Prod. 2016, 137, 1347-1367. [CrossRef]

28. Wang, X.; Li, X.R.; Zhen, F.; Zhang, J. How smart is your tourist attraction?: Measuring tourist preferences of smart tourism attractions via a FCEM-AHP and IPA approach. Tour. Manag. 2016, 54, 309-320. [CrossRef]

29. Kovačić, M. Selecting the location of a nautical tourism port by applying promethee and gaia methods case study-Croatian northern adriatic. Promet Traffic Transp. 2010, 22, 341-351. [CrossRef]

30. García-Melón, M.; Gómez-Navarro, T.; Acuña-Dutra, S. An ANP approach to assess the sustainability of tourist strategies for the coastal national parks of Venezuela. Technol. Econ. Dev. Econ. 2010, 16, 672-689. [CrossRef]

31. Ginevičius, R.; Podvezko, V. Evaluating the changes in economic and social development of Lithuanian counties by multiple criteria methods. Balt. J. Sustain. 2009, 15, 418-436. [CrossRef] 
32. Saaty, T.L. How to make a decision: The analytic hierarchy process. Eur. J. Oper. Res. 1990, 48, 9-26. [CrossRef]

33. Ramzan, N.; Degenkolbe, S.; Witt, W. Evaluating and improving environmental performance of HC's recovery system: A case study of distillation unit. Chem. Eng. J. 2008, 140, 201-213. [CrossRef]

34. Sólnes, J. Environmental quality indexing of large industrial development alternatives using AHP. Environ. Impact Assess. Rev. 2003, 23, 283-303. [CrossRef]

35. Šijanec, M.; Žarnić, R.; Šelih, J. Multicriterial sustainability assessment of residential buildings. Technol. Econ. Dev. Econ. 2009, 15, 612-630. [CrossRef]

36. Strojny, J. Implementation of the AHP and Benchmarking in Strategic Analysis of Polish Regions. Proc. Soc. Behav. Sci. 2015, 213, 229-235. [CrossRef]

37. Akbari, N.; Irawan, C.A.; Jones, D.F.; Menachof, D. A multi-criteria port suitability assessment for developments in the offshore wind industry. Renew. Energy 2017, 102, 118-133. [CrossRef]

38. De Lotto, R.; Gazzola, V.; Gossenberg, S.; Morelli di Popolo, C.; Venco, E.M. Proposal to Reduce Natural Risks: Analytic Network Process to Evaluate Efficiency of City Planning Strategies; Springer: Cham, Switzerland, 2016; pp. 650-664.

39. Wu, X.; Cui, P. A Study of the Time-Space Evolution Characteristics of Urban-Rural Integration Development in a Mountainous Area Based on ESDA-GIS: The Case of the Qinling-Daba Mountains in China. Sustainability 2016, 8, 1085. [CrossRef]

40. Saaty, T.L. The Analytic Network Process: Decision Making with Dependence and Feedback; RWS Publications: Pittsburgh, PA, USA, 2001.

41. Sipahi, S.; Timor, M. The analytic hierarchy process and analytic network process: an overview of applications. Manag. Decis. 2010, 48, 775-808. [CrossRef]

42. Peris, J.; García-Melón, M.; Gómez-Navarro, T.; Calabuig, C. Prioritizing Local Agenda 21 Programmes using Analytic Network Process: A Spanish Case Study. Sustain. Dev. 2013, 21, 338-352. [CrossRef]

43. Bottero, M.; Mondini, G. An appraisal of analytic network process and its role in sustainability assessment in Northern Italy. Manag. Environ. Qual. Int. J. 2008, 19, 642-660. [CrossRef]

44. Saaty, T.L.; Peniwati, K. Group Decision Making: Drawing out and Reconciling Differences; RWS Publications: Pittsburgh, PA, USA, 2008.

45. Shiau, T.A.; Chuen-Yu, J.K. Developing an indicator system for measuring the social sustainability of offshore wind power farms. Sustainability 2016, 8, 470. [CrossRef]

46. Ka, B. Application of fuzzy AHP and ELECTRE to China dry port location selection. Asian J. Shipp. Logist. 2011, 27, 331-354. [CrossRef]

47. Wang, Y.; Jung, K.-A.; Yeo, G.-T.; Chou, C.-C. Selecting a cruise port of call location using the fuzzy-AHP method: A case study in East Asia. Tour. Manag. 2014, 42, 262-270. [CrossRef]

48. Feng, L.; Zhu, X.; Sun, X. Assessing coastal reclamation suitability based on a fuzzy-AHP comprehensive evaluation framework: A case study of Lianyungang, China. Mar. Pollut. Bull. 2014, 89, 102-111. [CrossRef] [PubMed]

49. Shafiee, M. A fuzzy analytic network process model to mitigate the risks associated with offshore wind farms. Expert Syst. Appl. 2015, 42, 2143-2152. [CrossRef]

50. Deluka-Tibljaš, A.; Karleuša, B.; Šurdonja, S.; Dragičević, N. Use of AHP Multi-Criteria Method for Transportation Infrastructure Planning. In Proceedings of the International Scientific Conference: People, Buildings and Environment, Kroměříž, Czech Republic, 15-17 October 2014.

51. Erdogmus, S.; Aras, H.; Koc, E. Evaluation of alternative fuels for residential heating in Turkey using analytic network process (ANP) with group decision-making. Renew. Sustain. Energy Rev. 2006, 10, 269-279. [CrossRef]

52. Ulutaş, B.H. Determination of the appropriate energy policy for Turkey. Energy 2005, 30, $1146-1161$. [CrossRef]

53. Kao, L.-S.; Chiu, Y.-H.; Tsai, C.-Y. An Evaluation Study of Urban Development Strategy Based on of Extreme Climate Conditions. Sustainability 2017, 9, 284. [CrossRef]

54. García-Melón, M.; Gómez-Navarro, T.; Acuña-Dutra, S. A combined ANP-delphi approach to evaluate sustainable tourism. Environ. Impact Assess. Rev. 2012, 34, 41-50. 
55. Gómez-Navarro, T.; García-Melón, M.; Acuña-Dutra, S.; Díaz-Martín, D. An environmental pressure index proposal for urban development planning based on the analytic network process. Environ. Impact Assess. Rev. 2009, 29, 319-329. [CrossRef]

56. Chen, S.H.; Chen, C.M.; Lee, H.T. Tourism development planning using analytic network process. Int. J. Leis. Tour. Mark. 2009, 1, 70-86. [CrossRef]

57. Wolfslehner, B.; Vacik, H. Evaluating sustainable forest management strategies with the Analytic Network Process in a Pressure-State-Response framework. J. Environ. Manag. 2008, 88, 1-10. [CrossRef] [PubMed]

58. Wang, W.-M.; Lee, A.H.I.; Chang, D.-T. An integrated FDM-ANP evaluation model for sustainable development of housing community. Optim. Lett. 2010, 4, 239-257. [CrossRef]

59. Pourebrahim, S.; Hadipour, M.; Bin Mokhtar, M.; Mohamed, M.I.H. Analytic network process for criteria selection in sustainable coastal land use planning. Ocean Coast. Manag. 2010, 53, 544-551. [CrossRef]

60. Hasanzadeh, M.; Danehkar, A.; Azizi, M. The application of Analytical Network Process to environmental prioritizing criteria for coastal oil jetties site selection in Persian Gulf coasts (Iran). Ocean Coast. Manag. 2013, 73, 136-144. [CrossRef]

61. Hasanzadeh, M.; Danehkar, A. Environmental site selection for oil jetty using the analytical network process method case study: Boushehr, Iran. Ocean Eng. 2014, 77, 55-60. [CrossRef]

62. Najafinasab, F.; Karbassi, A.R.; Ghoddousi, J. Fuzzy analytic network process approach to evaluate land and sea criteria for land use planning in coastal areas. Ocean Coast. Manag. 2015, 116, 368-381. [CrossRef]

63. López, L.F.; Amezquita, J.; Sáenz, J.; Angulo, G.; Ramos, G. Serie Avances de Investigación 12: Brechas de Capital Humano en el Clúster Náutico de Cartagena; Cámara de Comercio de Cartagena: Cartagena, Colombia, 2015; Available online: http://www.cccartagena.org.co/sites/default/files/2015051223_inv_serie_avances_de_ investigacion_bch._no._12_v2.pdf (accessed on 14 December 2016). (In Spanish)

64. Corporación de Ciencia y Tecnología para el desarrollo de la industria naval, marítima y fluvial COTECMAR. Informe de gestión 2015; Cotecmar: Cartagena, Colombia, 2016; Available online: http:/ /www.cotecmar. com/sites/default/files/descargas/Informe\%20de\%20Gestion\%202015.pdf (accessed on 24 Febrary 2016). (In Spanish)

65. Alcaldía Distrital de Cartagena de Indias D. T. y C. Plan de Desarrollo "Primero la Gente" 2016-2019; Alcaldía Distrital de Cartagena de Indias: Cartagena, Colombia, 2016. Available online: http://www.siipe.co/wpcontent/uploads/2014/08/Plan-Cartagena.pdf (accessed on 24 October 2016). (In Spanish)

66. Alcaldía Distrital de Cartagena de Indias D. T. y C. Plan Sectorial del Turismo de Cartagena de Indias; Alcaldía Distrital de Cartagena de Indias: Cartagena, Colombia, 2014. Available online: http://sigob.cartagena. gov.co/Pd2016/Anexo\%206\%20Plan\%20Sectorial\%20de\%20Turismo.pdf (accessed on 24 October 2016). (In Spanish)

(C) 2017 by the authors. Licensee MDPI, Basel, Switzerland. This article is an open access article distributed under the terms and conditions of the Creative Commons Attribution (CC BY) license (http:/ / creativecommons.org/licenses/by/4.0/). 